\title{
PENGARUH IMPLEMENTASI KEBIJAKAN PERATURAN DAERAH NOMOR 12 TAHUN 2009 TENTANG KAWASAN TANPA ROKOK OLEH SATUAN POLISI PAMONG PRAJA TERHADAP PENEGAKAN DISIPLIN MASYARAKAT DI KAWASAN UMUM KOTA BOGOR
}

\section{THE EFFECT OF POLICY IMPLEMENTATION OF LOCAL REGULATION NO. 12/2009 CONCERNING AREAS WITHOUT CIGARETTES BY CIVIL SERVICE POLICE UNIT ON THE ENFORCEMENT OF PUBLIC DISCIPLINE IN THE PUBLIC AREAS OF BOGOR CITY}

\author{
Daman Huri1*, Denny Hernawan², G. Goris Seran³ \\ 1,2,3Program Studi Administrasi Publik, Fakultas Ilmu Sosial dan Ilmu Politik, Universitas \\ Djuanda, Jl. Tol Ciawi No. 1, Kotak Pos 35 Bogor 16720 \\ *Korespondensi: Daman Huri. Email: damanhuri@unida.ac.id
}

(Diterima: 14 November 2018; Ditelaah: 17 Desember 2018; Disetujui: 11 Februari 2019)

\begin{abstract}
The aim of the research is to analyze the effect of policy implementation of Local Regulation No. 12/2009 concerning Areas Without Cigarettes by Civil Service Police Unit on the enforcement of public discipline in the public areas of Bogor City. The policy implementation is understood in Edward III's perspective based on four aspects, namely communication, resource, disposition/attitude, and bureaucratic structure. The public discipline uses Elizabeth Hunrlock's perspective based on three aspects, namely rule/norm, consistence, punishment and reward. The research uses Weight Mean Score formula to count the mean and to describe it. It also uses Spearman Rank Correlation formula based on SPSS version.20 to test a hypothesis concerning the relation of policy implementation to public discipline. The results of the research indicate that the policy implementation gets the mean score 3.28, meaning good enough, and the public discipline gets the mean score 3.65 , meaning good. The coefficient correlation of two variables gets value 0.406 , categorized as the middle. By $t$-test, the research gets $t_{\text {count }}$ value 3.688 and $t_{\text {table }}(\mathrm{N}=71)$ value 1.666 . Therefore, $t_{\text {count }}>t_{\text {table }}$ means that alternative hypothesis is accepted. The coefficient determination indicates $16.4 \%$ of contribution of policy implementation to public discipline.
\end{abstract}

Keywords: Areas Without Cigarettes, Policy Implementation, Public Areas, Public Discipline.

\begin{abstract}
ABSTRAK
Penelitian ini bertujuan untuk mengetahui pengaruh implementasi kebijakan Peraturan Daerah Nomor 12 Tahun 2009 tentang Kawasan Tanpa Rokok oleh Satuan Polisi Pamong Praja terhadap penegakan disiplin masyarakat di kawasan umum Kota Bogor. Implementasi kebijakan dimaknai dalam perspektif Edward III berdasarkan empat dimensi, yaitu komunikasi, sumber daya, kecenderungan/sikap, dan struktur birokrasi. Disiplin masyarakat menggunakan pemikiran Elizabeth Hunrlock berdasarkan tiga dimensi, yaitu aturan/ norma, konsistensi, hukuman dan hadiah. Penelitian ini menggunakan Rumus Weight Mean Score untuk menghitung rata-rata dan menjelaskannya secara deskriptif. Penelitian ini juga memakai Rumus Korelasi Rank Spearman berdasarkan perhitungan SPSS versi.20 untuk menguji hipotesis hubungan implementasi kebijakan dengan disiplin masyarakat. Hasil penelitian menunjukkan skor rata-rata implementasi kebijakan sebesar 3,28 yang dinilai cukup baik dan skor rata-rata disiplin masyarakat sebesar 3,65 yang dinilai baik. Koefisien korelasi implementasi kebijakan dan disiplin masyarakat sebesar 0,406, yang dikategorikan sedang. Dengan rumus ttest, penelitian ini memperoleh nilai $t_{\text {hitung }}$ sebesar 3,688 dan $t_{\text {tabel }}(\mathrm{N}=71)$ sebesar 1,666. Dengan demikian, $t_{\text {hitung }}$ $>$ tabel berarti Ha diterima. Koefisien determinasi menunjukkan 16,4\% kontribusi implementasi kebijakan terhadap disiplin masyarakat.
\end{abstract}

Kata Kunci: Kawasan Tanpa Rokok, Implementasi Kebijakan, Kawasan Umum, Disiplin Masyarakat.

Daman Huri. 2019. Pengaruh Implementasi Kebijakan Peraturan Daerah Nomor 12 Tahun 2009 tentang Kawasan Tanpa Rokok oleh Satuan Polisi Pamong Praja terhadap Penegakan Disiplin Masyarakat di Kawasan Umum Kota Bogor. 


\section{PENDAHULUAN}

Kesehatan merupakan hal yang harus diperhatikan oleh setiap pemerintah di suatu kota. Tingkat kesehatan yang baik pada suatu kota akan berpengaruh pada tingkat kesehatan nasional. Semakin baik tingkat kesehatan penduduk pada suatu kota maka semakin baik pula tingkat kesehatan pada suatu negara. Pada masa kini, banyak orang yang tidak peduli dengan kesehatan sendiri. Pola hidup yang kurang baik dan kebiasaan buruk yang dilakukan oleh masyarakat dimana salah satunya adalah merokok.

Merokok suatu kegiatan yang sangat merugikan, tidak hanya bagi sang perokok atau yang sering disebut (perokok aktif) tapi juga bagi orang di sekitar atau yang sering disebut (perokok pasif). Setiap asap rokok yang ditimbulkan dari rokok, terkandung bahan-bahan yang berbahaya bagi kesehatan. Dalam bungkus rokok jelas disebutkan bahwa "rokok dapat membunuhmu". Namun sepertinya peringatan itu tidak dianggap serius bagi perokok aktif. Kerugian tidak hanya dirasakan bagi para perokok aktif, namun bagi perokok pasif, karena setiap asap yang terhisap juga berbahaya.

Pada tahun 2009 Kota Bogor mengeluarkan Peraturan Daerah tentang Kawasan Tanpa Rokok. Peraturan ini dimaksudkan salah satunya untuk mengatur para pecandu rokok atau perokok aktif di sembarang tempat sehingga tidak menggangu perokok pasif. Dalam Peraturan Daerah Kawasan Tanpa Rokok disebutkan bahwa ada beberapa tempat yang termasuk dalam kawasan tanpa rokok di antarantya: (a) Tempat umum; (b) Tempat kerja; (c) Tempat ibadah; (d) Tempat bermain dan berkumpulnya anak-anak; (e) Kendaraan umum; (f) Lingkungan tempat proses belajar-mengajar; (g) Sarana olahraga; dan (h) Sarana kesehatan.

Kawasan umum merupakan sarana yang sudah seharusnya memiliki lingkungan yang bersih, nyaman dan sehat.
Keberadaan rokok atau asap rokok di kawasan umum akan mengganggu kesehatan setiap masyarakat.

Perda KTR ini telah ditetapkan dan diberlakukan sejak tahun 2009. Namun pada kenyataan masih ditemukan banyak pelanggaran yang terjadi. Masih banyak dan sering ditemukan orang yang merokok di sembarang tempat, termasuk di kawasan umum.

Tabel 1. Laporan Hasil Monitoring dan Evaluasi Kawasan Tanpa Rokok di 8 Kawasan Umum Kota Bogor Tahun 2017

\begin{tabular}{|c|c|c|c|c|c|c|}
\hline \multirow[t]{3}{*}{ Kawasan } & \multicolumn{2}{|c|}{ Monev } & \multicolumn{4}{|c|}{ Tingkat Kepatuhan } \\
\hline & \multirow[t]{2}{*}{ Target } & \multirow[t]{2}{*}{ Realisasi } & \multicolumn{2}{|c|}{ Patuh } & \multicolumn{2}{|c|}{ Tidak Patuh } \\
\hline & & & Jlh & $\%$ & Jlh & $\%$ \\
\hline TTU & 578 & 463 & 224 & 17 & 239 & 26 \\
\hline $\begin{array}{l}\text { Olah } \\
\text { Raga }\end{array}$ & 34 & 25 & 14 & 1 & 11 & 1 \\
\hline Sekolah & 340 & 263 & 212 & 16 & 51 & 6 \\
\hline $\begin{array}{l}\text { Bermain } \\
\text { Anak }\end{array}$ & 136 & 100 & 80 & 6 & 20 & 2 \\
\hline Ibadah & 85 & 80 & 61 & 4 & 19 & 2 \\
\hline $\begin{array}{l}\text { Tempat } \\
\text { Kerja }\end{array}$ & 340 & 240 & 137 & 10 & 103 & 11 \\
\hline Sarkes & 187 & 144 & 123 & 9 & 21 & 2 \\
\hline Angkot & 640 & 789 & 499 & 37 & 452 & 50 \\
\hline Jumlah & 2340 & 2104 & 1350 & 100 & 916 & 100 \\
\hline
\end{tabular}

Grafik 1. Kepatuhan 8 Kawasan terhadap Perda KTR Kota Bogor Tahun 2015 dan 2016

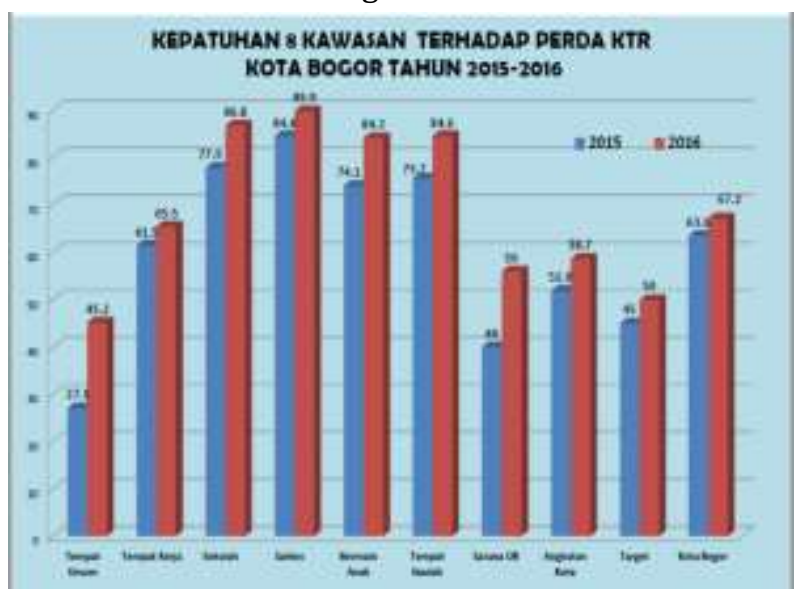

Sumber: Jurnal Penerapan dan Penegakan Perda KTR serta Pengaruh Iklan di Kota Bogor.

Penerapan Perda KTR menemui tantangan cukup sulit karena disiplin masyarakat yang masih kurang. Hasil inspeksi mendadak yang dilakukan oleh Satuan Polisi Pamong Praja (Satpol PP) Kota Bogor selaku penegak Perda KTR pada 
tanggal 29 Maret 2017 ditemukan 15 pelanggaran di antaranya 12 disidangkan dan 3 disidak di lingkungan pusat pembelanjaan Bogor Trade Mall (BTM). Pada 31 Agustus 2017 ditemukan 10 pelanggaran di lokasi yang sama, di antaranya 6 disidangkan dan 4 disidak kawasan tanpa rokok. Hasil inspeksi yang dilakukan oleh Satpol PP Kota Bogor telah ditemukan beberapa bukti pelanggaran kawasan tanpa rokok di dua lokasi tersebut, di antaranya: ditemukan asbak di tempat penjualan konter HP, food court, dan ditemukan puntung rokok, selain itu ada yang tertangkap tangan sedang merokok. Hal ini menunjukkan tingkat kepatuhan disiplin masyarakat masih belum maksimal (Sumber: Satuan Polisi Pamong Praja).

Penerapan Perda Nomor 12 Tahun 2009 ini tak lepas dari peran pengawasan dan pengendalian, dimana Walikota menunjuk SKPD (Satuan Kerja Perangkat Daerah) mempunyai tugas dan fungsi yaitu pengawasan dan pengendalian kawasan tanpa rokok. Salah satunya adalah Satuan Polisi Pamong Praja Kota Bogor sebagai aparat penegakan Peraturan Daerah.

Sebagai aparat penegakan Peraturan Daerah. Sesuai Undang-Undang Nomor 23 Tahun 2014 tentang Pemerintahan Daerah disebutkan, bahwa SatPol PP mempunyai tugas pokok membantu Kepala Daerah dalam penyelenggaraan ketentraman dan ketertiban umum serta penegakan. Ketertiban umum yang terkait langsung dengan Penegakan perda kawasan tanpa rokok yang diindikasikan belum bereskalasi luas menjadi tanggung jawab Sat Pol PP. Keberadaan Sat Pol PP di Kota Bogor merupakan bagian dari proses penegakan hukum sebagai perangkat pemerintah daerah yang diperlukan untuk mendukung suksesnya pelaksanaan otonomi daerah.

Untuk memberikan suatu efek jera bagi pelanggarnya, dalam Peraturan Daerah Nomor 12 tahun 2009 Kawasan Tanpa Rokok disebutkan bahwa bagi setiap pelanggar dapat dikenakan suatu sanksi administratif yang dijelaskan pada pasal 27 Perda Kawasan Tanpa Rokok.

Hal ini menarik peneliti untuk meneliti lebih mendalam tentang pengaruh implementasi kebijakan Peraturan Daerah Nomor 12 Tahun 2009 tentang Kawasan Tanpa Rokok oleh Satuan Polisi Pamong Praja terhadap penegakan disiplin masyarakat di kawasan umum Kota Bogor.

\section{MATERI DAN METODE}

\section{Konsep/Teori yang Relevan}

Ada dua konsep/variabel dalam penelitian ini, yaitu implementasi kebijakan dan disiplin masyarakat.

Implementasi kebijakan diartikan dalam perspektif Edward III (Nerustia, Rahmawati, dan Hernawan, 2015: 49). Edward III mengusulkan empat dimensi yang mempengaruhi implementasi kebijakan, yaitu:

Pertama: Komunikasi (Communication). Implementasi akan berjalan efektif apabila ukuran-ukuran dan tujuan kebijakan dipahami oleh individu yang bertanggung jawab dalam pencapaian tujuan.

Kedua: Sumber Daya (Resources). Dalam mengimplementasikan kebijakan, indikator sumber daya terdiri dari beberapa elemen yaitu staf, informasi, wewenang dan fasilitas.

Ketiga: Sikap (Disposition/Attitude). Salah satu faktor yang mempengaruhi efektivitas implementasi kebijakan adalah sikap implementasi.

Keempat: Struktur Birokrasi (Bureaucratic Structure). Pelaksana kebijakan dapat mendukung kebijakan yang telah diputuskan secara politik dengan cara melakukan koordinasi pelaksanaan dengan baik.

Sementara itu, disiplin masyarakat dimaknai dalam perspektif Elizabeth Hunrlock (Darji Darmodiharjo, 1991: 1620). Elizabeth Hunrlock mengemukakan tiga dimensi yang mempengaruhi disiplin masyarakat, yaitu: 
Pertama: Aturan/Norma. Fungsinya mengarahkan seseorang kepada keteraturan hidup yang diterima oleh kelompok. Apabila seseorang mengikuti aturan atau norma yang ditentukan, dengan kata lain lepas dari aturan dan norma maka ia akan bertindak sesuka hatinya, dan akan menemukan bahwa kelompok sosial tidak akan mentolelir dirinya.

Kedua: Konsitensi atau Konsekuen. Fungsinya menanamkan keteguhan dalam memegang prinsip kepada seseorang. Jika disiplin tidak konsisten maka seseorang akan kehilangan kendali tentang apa yang dapat ia lakukan dan kepada siapa ia harus patuh.

Ketiga: Hukuman dan Hadiah. Hukuman berfungsi untuk menghalangi perbuatan-perbuatan yang tidak diinginkan, sementara hadiah bertindak untuk mendorong atau merangsang perbuatanperbuatan yang diinginkan. Oleh karena itu, bila hukuman dan hadiah menyumbang kepada kesehatan pertumbuhan mental dan emosional seseorang, maka hukuman dan hadiah sebaiknya digunakan secara tepat.

\section{Metode Penelitian}

Pendekatan Penelitian: Pendekatan penelitian adalah keseluruhan cara atau kegiatan dalam suatu penelitian yang dimulai dari perumusan masalah sampai membuat suatu kesimpulan. Pendekaan penelitian ada dua macam yaitu pendekatan kuantitatif dan pendekatan kualitatitif. Pendekatan kuantitatif artinya informasi atau data yang disajikan berupa angka sedangkan pendekatan kualitatif informasi atau data yang disajikan berupa pernyataan.

Metode Penelitian: Metode penelitian yang digunakan adalah metode asosiatif/ hubungan dimana penelitian ini bertujuan untuk mengetahui hubungan dua variabel atau lebih. Dalam hal ini, penelitian dimaksud ditujukan untuk menguji hubungan antara implementasi kebijakan (variabel bebas) dan disiplin masyarakat (variabel terikat).

Jenis dan Teknik Pengumpulan Data: Untuk memperoleh data yang diper-lukan, peneliti menggunakan beberapa teknik penelitian pengumpulan data sebagai berikut:

Pertama: Studi Kepustakaan. Teknik ini memperoleh data sekunder dengan membaca, mempelajari, megutip, dan merangkum data berkaitan dengan pengaruh implementasi kebijakan Peraturan Daerah Nomor 12 Tahun 2009 tentang Kawasan Tanpa Rokok oleh Satuan Polisi Pamong Praja terhadap disiplin masyarakat di kawasan umum Kota Bogor.

Kedua: Studi Lapangan. Teknik ini mendapatkan data primer dengan cara melakukan pengamatan langsung di tempat di Satuan Polisi Pamong Praja Kota Bogor dan kawasan umum Bogor Trade Mall (BTM).

Pada studi lapangan, peneliti menggunakan wawancara dan menyebarkan angket. Wawancara dilakukan untuk mengumpulkan data dengan tanya jawab secara lisan kepada responden tentang pengaruh implementasi kebijakan Peraturan Daerah Nomor 12 Tahun 2009 tentang Kawasan Tanpa Rokok oleh Satuan Polisi Pamong Praja terhadap Disiplin Masyarakat di Kawasan Umum Kota Bogor.

Di samping wawancara, peneliti menggunakan angket. Angket merupakan teknik pengkumpulan data dengan cara yaitu memberikan pertanyaan kepada responden untuk dijawab. Peneliti membagikan daftar pertanyaan kepada masyarakat. Angket ini bersifat tertutup dan menggunakan Skala Likert. Skala Likert digunakan untuk mengukur sikap, pendapat, persepsi seseorang atau sekelompok orang tentang fenomena sosial tertentu (Sugiyono, 2012: 107).

Pengolahan dan Analisis Data: Dalam menganalisis data, peneliti mengelompok- 
kan data berdasarkan variabel dan jenis suatu responden, lalu mentabulasi data dan menyajikan data tiap variabel yang diteliti, dengan melakukan perhitungan untuk menjawab rumusan masalah, dan melakukan perhitungan menguji hipotesis yang telah diajukan.

Skala pengukuran dalam penelitian ini menggunakan Skala Likert. Skala Likert terbagi dalam 5 skor, dari skor tersebut akan diperoleh variasi jawaban yang bergerak dari 1-5.

Analsis deskriptif (Lesmana, Rahmawati, dan Seran, 2015: 5) digunakan untuk menganalisis data dengan cara mendeskripsikan atau menggambarkan data yang telah terkumpul sebagaimana adanya, tanpa bermaksud membuat kesimpulan yang berlaku untuk umum dan generalisasi. Rumus yang digunakan adalah Weight Mean Score (WMS) untuk menghitung rata-rata dan kemudian mendeskripsikannya.

Analisis asosiatif digunakan untuk menganalisis hubungan antara dua variabel atau lebih. Dalam hal ini, peneliti mencoba mengemukakan dan menjelaskan apa yang ditemukan di lapangan dengan cara asosiatif. Dengan penelitian ini, dibangun konstruksi yang berfungsi untuk menjelaskan, meramalkan, dan mengontrol suatu gejala.

Uji korelasi menggunakan Rank Spearman dengan tujuan menguji apakah terdapat hubungan kausal/sebab akibat yang signifikan antara suatu variabel yang bebas dan terikat atau menguji hipotesis Rank Spearman. Penelitian ini ingin melihat hubungan kausal/sebab akibat perda kawasan tanpa rokok dengan disiplin merokok dikawasan umum. Perhitungan rumus Rank Spearman dilakukan menggunakan Statistical Package for Social Sciences (SPSS) versi 20.

Untuk mengetahui signifikansi korelasi hubungan anatara dua variabel, peneliti melakukan uji t. Dan untuk mengetahui besarnya kontribusi yang ditimbulkan dari variabel implementasi kebijakan (X) terhadap variabel disiplin masyarakat (Y) peneliti menggunakan rumus Koefisien Determinasi.

\section{HASIL DAN PEMBAHASAN}

\section{Implementasi Kebijakan Peraturan Daerah Nomor 12 Tahun 2009 tentang Kawasan Tanpa Rokok di Kawasan Umum Kota Bogor}

Adapun hasil penelitian tentang implementasi kebijakan berdasarkan ukuran tiap dimensi dapat dilihat dalam penjelasan sebagai berikut:

Tabel 2. Rekapitulasi Dimensi Komunikasi

\begin{tabular}{|c|c|c|c|}
\hline Dimensi & Indikator & $M$ & $\begin{array}{c}\text { Kriteria } \\
\text { Penafsiran }\end{array}$ \\
\hline \multirow[t]{3}{*}{ Komunikasi } & $\begin{array}{l}\text { Implementor } \\
\text { Mengetahui Apa yang } \\
\text { Harus Dikerjakan }\end{array}$ & 2,90 & Cukup Baik \\
\hline & $\begin{array}{l}\text { Adanya Faktor } \\
\text { Penyebab dan Akibat }\end{array}$ & 2,98 & Cukup Baik \\
\hline & $\begin{array}{l}\text { Tingkat Kejelasan dan } \\
\text { Konsitensi Tujuan }\end{array}$ & 3,38 & Cukup Baik \\
\hline Jumlah & $\begin{array}{l}\text { Total Jawaban } \\
\text { Responden } \\
M=\frac{\sum \text { Skor }}{\text { Jumlah Indikator }}\end{array}$ & 9,26 & Cukup Baik \\
\hline
\end{tabular}

Sumber: Hasil Penelitian, 2018.

Tabel 2 menunjukkan rekapitulasi dimensi Komunikasi diperoleh skor akhir 3,08 yang menurut penafsiran cukup baik. Hal ini menunjukkan implementor mengetahui apa yang akan dikerjakan dan menilai bahwa tingkat kejelasan dan konsistensi tujuan kebijakan jelas dimana salah satu fungsinya adalah untuk melindungi masyarakat (perokok pasif). Selain itu masyarakat bisa menikmati udara bersih dan sehat yang terhindar dari asap rokok, khususnya di kawasan umum.

Tabel 3. Rekapitulasi Dimensi Sumber Daya

\begin{tabular}{llcl}
\hline Dimensi & Indikator & $\mathrm{M}$ & $\begin{array}{c}\text { Kriteria } \\
\text { Penafsiran }\end{array}$ \\
\hline $\begin{array}{l}\text { Sumber } \\
\text { Daya }\end{array}$ & $\begin{array}{l}\text { Kecukupan Sumber } \\
\text { Daya Manusia }\end{array}$ & 3,23 & Cukup Baik \\
\cline { 2 - 4 } & Kecukupan Anggaran & 3,14 & Cukup Baik \\
\cline { 2 - 4 } & $\begin{array}{l}\text { Komitmen yang } \\
\text { Dilaksanakan dengan } \\
\text { Baik }\end{array}$ & 3,02 & Cukup Baik \\
\hline Jumlah & $\begin{array}{l}\text { Total Jawaban } \\
\text { Responden }\end{array}$ & 9,39 & \\
& $\begin{array}{l}\text { CSkor } \\
\text { Jumlah Indikator }\end{array}$ & 3,13 & \\
\hline
\end{tabular}

Sumber: Hasil Penelitian, 2018. 
Tabel 3 menunjukkan rekapitulasi dari dimensi Sumber Daya diperoleh skor akhir 3,13 yang menurut penafsiran cukup baik. Hal ini dikarenakan kecukupan anggota Sat Pol PP cukup memadai ketika melakukan kegiatan operasi Kawasan Tanpa Rokok. Didukung dengan kecukupan anggaran dalam terkait kegiatan operasi Kawasan Tanpa Rokok, dan komitmen pelakasanaan cukup baik, tetapi belum optimal.

Tabel 4. Rekapitulasi Dimensi Disposisi

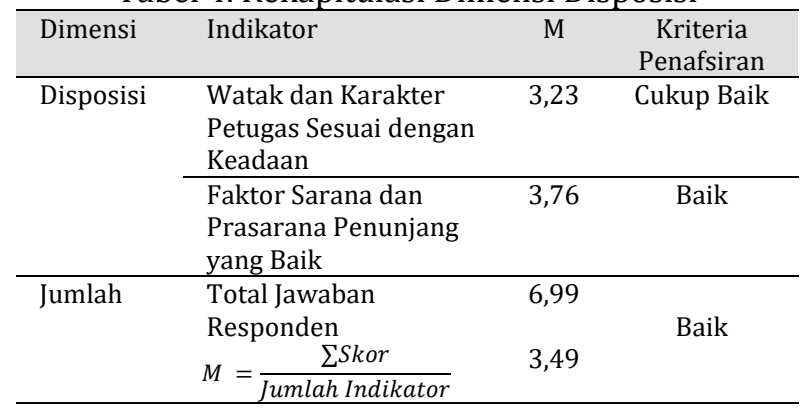

Sumber: Hasil Penelitian, 2018.

Tabel 4 menunjukkan rekapitulasi dari dimensi Disposisi diperoleh skor akhir 3,49 yang menurut penafsiran berada dalam kategori baik. Hal ini dikarenakan watak dan karakter Sat Pol PP dalam pelaksanaan kegiatan penegakan perda KTR sesuai prosedur, maka dalam pelaksanaan dilapangan sesuai dengan aturan yang benar. Selain dari itu faktor sarana dan prasarana menunjang dengan adanya mobil sidang di Satuan Polisi Pamong Praja.

Tabel 5. Rekapitulasi Dimensi Struktur Birokrasi

\begin{tabular}{llcc}
\hline Dimensi & Indikator & M & $\begin{array}{c}\text { Kriteria } \\
\text { Penafsiran }\end{array}$ \\
\hline $\begin{array}{l}\text { Struktur } \\
\text { Birokrasi }\end{array}$ & $\begin{array}{l}\text { Adanya Koordinasi Antar } \\
\text { Instasi yang Baik }\end{array}$ & 3,43 & Baik \\
\hline Jumlah & $\begin{array}{l}\text { Total Jawaban } \\
\text { Responden }\end{array}$ & 3,43 & \multirow{2}{*}{ Baik } \\
\cline { 2 - 3 } & $M=\frac{\sum \text { Skor }}{\text { Jumlah Indikator }}$ & 3,43 & \\
\hline
\end{tabular}

Sumber: Hasil Penelitian, 2018.

Tabel 5 menunjukkan rekapitulasi dari dimensi Struktur Birokrasi diperoleh skor akhir 3,43 yang menurut penafsiran berada dalam kategori baik. Hal ini dikarenakan dari pertama lahirnya Perda Kawasan Tanpa Rokok ini sudah menadatangani fakta intergritas yaitu bahwa semua elemen semua unsur mendukung dengan adanya perda ini, (Muspida) Musyawarah Antar Pimpinan Daerah. Sehingga koordinasi dengan instansi lain terjalan dengan baik.

Tabel 6. Rekapitulasi Rata-Rata Skor Keseluruhan Dimensi pada Variabel Implementasi Kebijakan

\begin{tabular}{lcc}
\hline Dimensi & M & Kriteria Penafsiran \\
\hline Komunikasi & 3,08 & Cukup Baik \\
\hline Sumber Daya & 3,13 & Cukup Baik \\
\hline Disposisi & 3,49 & Baik \\
\hline Struktur Birokrasi & 3,43 & Baik \\
\hline Total Jawaban Dimensi & 13,13 & \multirow{2}{*}{ Cukup Baik } \\
\cline { 1 - 2 }$M=\frac{\sum \text { Skor }}{\text { Jumlah Dimensi }}$ & 3,28 & \\
\hline Sum & &
\end{tabular}

Sumber: Hasil Penelitian, 2018.

Tabel 6 menunjukkan rekapitulasi dari keseluruhan dimensi pada variabel implementasi kebijakan diperoleh skor akhir 3,28 yang menurut penafsiran berada dalam kategori cukup baik. Artinya penilaian responden tentang dimensi komunikasi, sumber daya, sikap, dan struktur birokrasi secara garis besar adalah baik.

Hal ini tersebut menunjukkan implementor mengetahui apa yang dikerjakan. Dan responden menilai bahwa kebijakan ini tingkat kejelasan dan kosintensi tujuannya jelas dimana salah satu fungsinya untuk melindungi perokok pasif. Dan masyarakat bisa menikmati udara bersih, serta sehat yang terhindar dari asap rokok, khususnya di kawasan umum.

Selain itu, kecukupan anggota Sat Pol PP Kota Bogor memadai ketika melakukan kegiatan operasi Kawasan Tanpa Rokok. dan komitmen pelakasanaan cukup baik namun, masih belum optimal. Watak dan karakter pelaksanaan kegiatan penegakan Perda KTR sesuai prosedur, yang didukung dengan faktor sarana dan prasarana menunjang dengan adanya mobil sidang. Dan kordinasi terjalan dengan instansi terkait. 


\section{Penegakan Disiplin Masyarakat di Kawasan Umum Kota Bogor}

Adapun hasil penelitian tentang disiplin masyarakat berdasarkan ukuran tiap dimensi dapat dilihat dalam penjelasan sebagai berikut:

Tabel 7. Rekapitulasi Dimensi Aturan/Norma

\begin{tabular}{llcc}
\hline Dimensi & Indikator & $\mathrm{M}$ & $\begin{array}{c}\text { Kriteria } \\
\text { Penafsiran }\end{array}$ \\
\hline $\begin{array}{l}\text { Aturan/ } \\
\text { Norma }\end{array}$ & $\begin{array}{l}\text { Pemahaman tentang } \\
\text { Perda }\end{array}$ & 3,26 & Cukup Baik \\
\cline { 2 - 3 } & $\begin{array}{l}\text { Keberhasilan Disiplin } \\
\text { Kebijakan }\end{array}$ & 4,25 & Sangat Baik \\
\hline Jumlah & $\begin{array}{l}\text { Total Jawaban } \\
\text { Responden }\end{array}$ & 7.51 & \\
\cline { 2 - 3 } & $M=\frac{\sum \text { Skor }}{\text { Jumlah Indikator }}$ & 3,75 & Baik \\
\hline
\end{tabular}

Sumber: Hasil Penelitian, 2018.

Tabel 7 menunjukkan rekapitulasi dari dimensi Aturan atau Norma diperoleh skor akhir 3,75 yang menurut penafsiran berada dalam kategori baik. Hal ini dikarenakan masyarakat yang berada dikawasan umum BTM sudah cukup memahami tentang keberadaan Perda Kawasan Tanpa Rokok. Dan responden menilai bahwa kebijakan ini telah berhasil dilaksanakan.

Tabel 8. Rekapitulasi Dimensi Konsitensi/Konsekuen

\begin{tabular}{|c|c|c|c|}
\hline Dimensi & Indikator & $\mathrm{M}$ & $\begin{array}{c}\text { Kriteria } \\
\text { Penafsiran }\end{array}$ \\
\hline \multirow{3}{*}{$\begin{array}{l}\text { Konsitensi/ } \\
\text { Konsekuen }\end{array}$} & Proses Sosialisasi & 3,73 & Baik \\
\hline & $\begin{array}{l}\text { Konsitensi } \\
\text { Pengawasan dalam } \\
\text { Pelaksanaan }\end{array}$ & 3,39 & Cukup Baik \\
\hline & $\begin{array}{l}\text { Manfaat Pelaksanaan } \\
\text { Kebijakan }\end{array}$ & 3,77 & Baik \\
\hline \multirow[t]{2}{*}{ Jumlah } & $\begin{array}{l}\text { Total Jawaban } \\
\text { Responden }\end{array}$ & 10,89 & \multirow[t]{2}{*}{ Baik } \\
\hline & $M=\frac{\sum \text { Skor }}{\text { Jumlah Indikator }}$ & 3,63 & \\
\hline
\end{tabular}

Sumber: Hasil Penelitian, 2018.

Tabel 8 menunjukkan rekapitulasi dari dimensi dalam Konsitensi atau Konsekuen diperoleh skor akhir 3,63 yang menurut penafsiran berada dalam kategori baik. Hal ini dikarenakan proses sosialisai yang dilakukan cukup baik, selain itu konsitensi pengawasanpun dilakukan dengan kontiyu 2-3 kali dalam satu bulan, dibantu dengan pihak pengelola kawasan umum BTM yang sudah mempunyai petugas (KTR) kawasan tanpa rokok. Dan keberadan peraturan daerah ini telah banyak memberikan manfaat diantaranya lingkungan dikawasan umum menjadi bersih, sehat dan tidak tercemar dengan bahaya asap rokok, terutama pada kawasan umum ini.

Tabel 9. Rekapitulasi Dimensi Hukuman dan Hadiah

\begin{tabular}{llcc}
\hline Dimensi & Indikator & M & $\begin{array}{c}\text { Kriteria } \\
\text { Penafsiran }\end{array}$ \\
\hline Hukuman & Penerpan Sanksi & 3,39 & Cukup Baik \\
\cline { 2 - 4 } dan & Fasilitas Penunjang & 3,46 & Baik \\
\cline { 2 - 4 } Hadiah & $\begin{array}{l}\text { Pengaruh setelah } \\
\text { Disiplin Dilaksanakan }\end{array}$ & 3,85 & Baik \\
\cline { 2 - 4 } & $\begin{array}{l}\text { Penurunan Jumlah } \\
\text { Pelanggaran yang } \\
\text { Terjadi }\end{array}$ & 3,63 & Baik \\
\hline Jumlah & $\begin{array}{l}\text { Total Jawaban } \\
\text { Responden }\end{array}$ & 14,33 & \\
& $M=\frac{\sum \text { Skor }}{\text { Jumlah Indikator }}$ & 3,58 & Baik \\
\hline
\end{tabular}

Sumber: Hasil Penelitian, 2018.

Tabel 9 menunjukkan rekapitulasi dari dimensi Hukuman dan Hadiah diperoleh skor akhir 3,58 yang menurut penafsiran berada dalam kategori baik. Hal ini dikarenakan sanksi yang ada masih belum memeberikan efek jera bagi pelanggarnya, namun fasilitas penunjang cukup memadi semisal dikawasan umum BTM sudah ada berupa stiker atau billboard larangan merokok dengan adanya kebijkan ini pengaruh yang dirasakan yaitu angka kepatuhan disiplin meningkat dan mulai timbulnya sungkan atau malu merokok dikawasan umum khususnya di BTM ini. Penurunan jumlah pelanggaran yang terjadi juga terus menurun meskipun belum 100\%.

Tabel 10. Rekapitulasi Rata-Rata Skor Keseluruhan Dimensi pada Variabel Disiplin Masyarakat

\begin{tabular}{lcc}
\hline Dimensi & M & Kriteria Penafsiran \\
\hline Aturan/Norma & 3.75 & Baik \\
\hline Konsitensi/Konsekuen & 3,63 & Baik \\
\hline Hukuman dan Hadiah & 3,58 & Cukup Baik \\
\hline Total Jawaban Dimensi & 10,96 & Baik \\
\cline { 1 - 1 }$M=\frac{\sum \text { Skor }}{\text { Jumlah Dimensi }}$ & 3,65 & \\
\hline
\end{tabular}

Sumber: Hasil Penelitian, 2018.

Tabel 10 menunjukkan Rekapitulasi dari keseluruhan dimensi pada variabel Disiplin Masyarakat diperoleh skor akhir 3,65 yang menurut penafsiran berada 
dalam kategori baik. Artinya penilian responden tentang dimensi aturan atau norma, konsitensi atau konsekuen dan hukuman atau hadiah secara garis besar adalah baik.

Hal ini tersebut menunjukkan masyarakat yang berada dikawasan umum sudah cukup memahami tentang keberadaan Perda Kawasan Tanpa Rokok, juga kebijakan ini telah berhasil dilaksanakan. Proses sosialisasi yang dilakukan cukup baik, pengawasan pun dilakukan dengan kontiyu 2-3 kali dalam satu bulan, dibantu dengan pihak pengelola kawasan umum BTM yang sudah mempunyai petugas KTR dimana keberadan peraturan kawasan tanpa rokok telah banyak memberikan manfaat di antaranya lingkungan yang berada di kawasan umum BTM menjadi bersih, sehat dan tidak tercemar dengan bahaya asap rokok, khususnya dikawasan umum BTM.

Di samping itu, fasilitas penunjang cukup memadai semisal di kawasan umum BTM sudah ada berupa stiker atau billboard larangan merokok dengan adanya kebijakan ini pengaruh yang dirasakan yaitu angka kepatuhan disiplin meningkat dan mulai timbulnya sungkan atau malu merokok di kawasan umum khususnya di Mall BTM ini, dan jumlah pelanggaran yang terjadi juga terus menurun meskipun belum $100 \%$.

\section{Pengaruh Implementasi Kebijakan Peraturan Daerah Nomor 12 Tahun 2009 tentang Kawasan Tanpa Rokok terhadap Penegakan Disiplin Masyarakat di Kawasan Umum Kota Bogor}

Dalam kaitan dengan pengaruh implementasi kebijakan Peraturan Daerah No 12 tahun 2009 tentang Kawasan Tanpa Rokok terhadap penegakan disiplin masyarakat di kawasan umum Kota Bogor, dapat dilihat pada rekapitulasi antara implementasi kebijakan (X) terhadap disiplin masyarakat (Y) sebagai berikut:
Tabel 11. Rekapitulasi Rata-Rata Skor Keseluruhan Variabel Implementasi Kebijakan (X) dan Variabel Disiplin Masyarakat (Y)

\begin{tabular}{|c|c|c|}
\hline Variabel & M & Kriteria Penafsiran \\
\hline Implementasi Kebijakan & 3,28 & Cukup Baik \\
\hline Disiplin Masyarakat & 3,65 & Baik \\
\hline Total Jawaban Variabel & 6,93 & \\
\hline$M=\frac{\sum S k o r}{\text { Jumlah Variabel }}$ & 3,46 & Baik \\
\hline
\end{tabular}

Sumber: Hasil Penelitian, 2018.

Berdasarkan hasil rekapitulasi antara implementasi kebijakan (X) terhadap disiplin masyarakat (Y) diperoleh nilai ratarata sebesar 3,46 dengan peafsiran pada kategori baik.

Hasil uji statistik korelasi Rank Spearman terhadap hubungan variabel implementasi kebijakan dengan variabel disiplin masyarakat ditunjukkan sebagai berikut:

Tabel 12. Hasil Uji Statistik Korelasi Rank Spearman

\begin{tabular}{|c|c|c|c|}
\hline & & $\begin{array}{l}\text { Implementasi } \\
\text { Kebijakan (X) }\end{array}$ & $\begin{array}{c}\text { Disiplin } \\
\text { Masyarakat } \\
(\mathrm{Y})\end{array}$ \\
\hline \multirow[t]{3}{*}{$\begin{array}{l}\text { Implementasi } \\
\text { Kebijakan (X) }\end{array}$} & $\begin{array}{l}\text { Correlation } \\
\text { Coefficient }\end{array}$ & 1.000 & $0.406^{* *}$ \\
\hline & $\begin{array}{l}\text { Sig. (2- } \\
\text { tailed) }\end{array}$ & & .000 \\
\hline & $\mathrm{N}$ & 71 & 71 \\
\hline \multirow{3}{*}{$\begin{array}{l}\text { Disiplin } \\
\text { Masyarakat } \\
\text { (Y) }\end{array}$} & $\begin{array}{l}\text { Pearson } \\
\text { Correlation }\end{array}$ & $0.406^{* *}$ & 1.000 \\
\hline & $\begin{array}{l}\text { Sig. (2- } \\
\text { tailed) }\end{array}$ & 0.000 & \\
\hline & $\mathrm{N}$ & 71 & 71 \\
\hline
\end{tabular}

**.Correlation is significant at the 0.01 level (2-tailed).

Sumber: SPSS version. 20 for windows

Berdasarkan hasil uji statistik korelasi Rank Spearman diperoleh koefisien korelasi antara implementasi kebijakan terhadap disiplin masyarakat sebesar 0,406**. Dapat disimpulkan, bahwa terdapat pengaruh antara variabel implementasi kebijakan terhadap disiplin masyarakat, penelitian tersebut berdasarkan interpretasi koefisien korelasi tingkat hubungannya termasuk pada kategori sedang.

Kemudian, uji hipotesis dilakukan untuk mengetahui apabila diterima atau ditolaknya hipotesis. Adapun pengujian signifikan koefisien korelasi dengan, rumus t-tes sebagai berikut: 


$$
\begin{aligned}
t & =r \sqrt{\frac{N-2}{1-r^{2}}} \\
& =0,406 \sqrt{\frac{71-2}{1-0,164}} \\
& =0,406 \sqrt{82,53} \\
& =3,688
\end{aligned}
$$

Berdasarkan hasil rumus t-test, diperoleh nilai thitung sebesar 3,688 dan ttabel $(\mathrm{N}=71)$ adalah sebesar 1,666 maka thitung $>$ tabel yang berarti ho ditolak dan ha diterima, artinya terdapat pengaruh signifikan antara implementasi kebijakan Peraturan Daerah Nomor 12 Tahun 2009 tentang Kawasan Tanpa Rokok terhadap penegakan disiplin masyarakat di kawasan umum Kota Bogor.

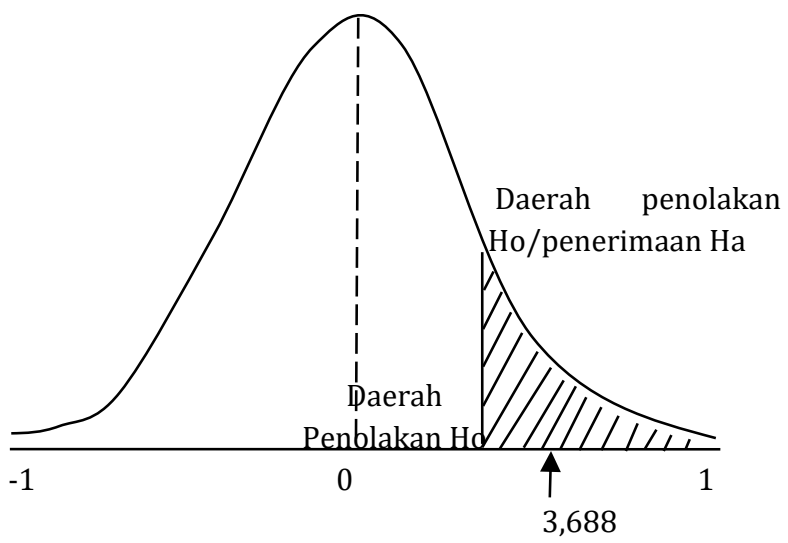

Gambar 1. Hasil Uji-t Koefisien Korelasi Sumber: Data Primer diolah, 2018

Untuk mengetahui kontribusi variabel implementasi kebijakan (X) menentukan variabel disiplin masyarakat (Y) di dalam penelitian ini, maka digunakan perhitungan koefisien determinasi (Kd), yaitu:

$$
\begin{aligned}
\text { Kd } & =\rho^{2} \times 100 \% \\
& =0,406^{2} \times 100 \% \\
& =0,164 \times 100 \% \\
& =16.4 \%
\end{aligned}
$$

Dengan demikian dapat ditafsirkan besarnya kontribusi variabel (X) yaitu implementasi kebijakan terhadap variabel (Y) yaitu penegakan disiplin masyarakat sebesar $16,4 \%$, sementara kontribusi faktor lain adalah sebesar 83,6\%.

\section{KESIMPULAN DAN IMPLIKASI}

\section{Kesimpulan}

Hasil analisis data dan pembahasan yang diperoleh pada penelitian mengenai pengaruh implementasi kebijakan Peraturan Daerah Nomor 12 Tahun 2009 tentang Kawasan Tanpa Rokok oleh Satuan Polisi Pamong Praja terhadap penegakan disiplin masyarakat di kawasan umum Kota Bogor dapat ditarik kesimpulan sebagai berikut:

Pertama: Implementasi kebijakan Peraturan Daerah Nomor 12 Tahun 2009 tentang Kawasan Tanpa Rokok di kawasan umum Kota Bogor mendapatkan skor 3,28 yang dinilai cukup baik. Faktor yang paling tinggi nilainya ada pada dimensi disposisi dengan rata-rata skor sebesar 3,49. Sedangkan skor paling rendah ada pada dimensi komunikasi dengan rata-rata 3.08. Hal ini menunjukan bahwa implementasi kebijakan Perda KTR di kawasan umum Kota Bogor dinilai cukup baik.

Kedua: Penegakan disiplin masyarakat di kawasan umum Kota Bogor oleh Satuan Polisi Pamong Praja mempunyai skor 3,65 yang dinilai baik. Faktor yang paling tinggi nilainya ada pada dimensi aturan atau norma dengan rata-rata skor sebesar 3,75. Sedangkan skor paling rendah ada pada dimensi hukuman dan hadiah dengan ratarata 3,58. Namun secara keseluruhan hasil rekapitulasi penelitian tentang penegakan disiplin masyarakat di kawasan umum Kota Bogor oleh Satuan Polisi Pamong Praja dinilai baik.

Ketiga: Berdasarkan hasil analisis Software SPSS Versi 20 yang diolah untuk mengetahui korelasi hubungan pengaruh yaitu hasil uji statistik korelasi Rank Spearman diperoleh koefisien korelasi antara implementasi kebijakan terhadap disiplin masyarakat sebesar 0,406. Dapat disimpulkan yaitu terdapat pengaruh implementasi kebijakan terhadap disiplin masyarakat, penelitian tersebut berdasarkan interpretasi koefisien korelasi tingkat hubungannya termasuk pada kategori sedang. Dan berdasarkan hasil rumus t-test, diperoleh nilai thitung sebesar 3,688 dan 
ttabel $(\mathrm{N}=71)$ adalah sebesar 1,666 maka thitung $>$ ttabel yang berarti ho ditolak dan ha diterima artinya ada pengaruh yang signifikan antara implementasi kebijakan Perda Kawasan Tanpa Rokok terhadap disiplin masyarakat di kawasan umum Kota Bogor. Sedangkan sejauhmana variabel Implementasi Kebijakan (X) mempengaruhi variabel disiplin masyarakat $(\mathrm{Y})$ dalam penelitian ini, menggunakan perhitungan koefisien determinasi (Kd) yang hasilnya ditafsirkan besarnya kontribusi variabel (X) yaitu implementasi kebijakan terhadap variabel (Y) yaitu disiplin masyarakat sebesar 16,4\% dan kontribusi faktor lain adalah sebesar $83,6 \%$.

Berdasarkan uraian hasil penelitian, maka peneliti merekomendasikan hal-hal sebagai berikut:

1. Di dalam dimensi komunikasi Satuan Polisi Pamong Praja diharapkan lebih memahami tentang Standar Operasional Prosedur (SOP), Tugas dan Fungsinya. Selain itu Satuan Polisi Pamong Praja dapat aktif lagi dalam mensosialisasikan Perda Kawasan Tanpa Rokok khususnya di kawasasan umum Kota Bogor.

2. Di dalam dimensi sumber daya Satuan Polisi Pamong Praja Bidang Penegakan Perda Kota Bogor diharapkan untuk menambahkan jumlah Sumber Daya Manusia (SDM), anggaran, serta komitmen di dalam penegakan Perda lebih ditingkatkan khususnya pada kawasan umum Kota Bogor.

3. Di dalam dimensi hukuman dan hadiah Satuan Polisi Pamong Praja, untuk lebih meningkatkan pengawasan di kawasan umum dilakukan dengan sidak atau tipiring, serta sanksi agar memberikan efek jera bagi pelanggarnya.

4. Penelitian selanjutnya dapat dilakukan pada kawasan umum mall-mall yang berada di Kota Bogor.

5. Penelitian selanjutnya disarankan untuk meneliti lebih jauh dalam penegakan Kawasan Tanpa Rokok yang lain, serta faktor lain yang dapat meningkatkan kepatuhan masyarakat dengan adanya kebijakan kawasan tanpa rokok.

6. Kawasan umum khususnya mall-mall yang berada di Kota Bogor harus menambah fasilitas berupa stiker atau billboard larangan merokok dan mallmall yang berada di Kota Bogor dapat membuat ruangan khusus merokok supaya dapat berjalan maksimal kebijakan kawasan tanpa rokok khususnya di kawasan umum.

\section{Implikasi}

Implikasi teoritis dari penelitian ini adalah bahwa setiap asap rokok yang ditimbulkan dari rokok, terkandung bahan-bahan yang berbahaya bagi kesehatan. Semakin banyak orang yang merokok, maka semakin banyak juga bahaya yang dapat ditimbulkan. Dalam bungkus rokok jelas disebutkan bahwa "rokok dapat membunuhmu". Akan tetapi sepertinya peringatan ini tidak dianggap serius bagi para perokok aktif. Kerugian tidak hanya dirasakan bagi pecandu perokok aktif namun bagi perokok pasif, karena setiap asap yang terhisap juga berbahaya. Karena itu tahun 2009 Kota Bogor mengeluarkan Peraturan Daerah Nomor 12 Tahun 2009 tentang Kawasan Tanpa Rokok. Peraturan ini dimaksudkan untuk mengatur para perokok aktif agar tidak merokok di sembarang tempat sehingga tidak menganggu perokok pasif, atau orang lain yang tidak merokok.

Implikasi praktis dari penelitian ini adalah bahwa hasil penelitian ini diharapkan dapat bermanfaat sebagai bahan masukan untuk pertimbangan sebagai bahan masukan untuk pertimbangan dan sumbangan pemikiran yang bermanfaat mengenai masalah yang menyangkut implementasi kebijakan Peraturan Daerah Nomor 12 tahun 2009 tentang Kawasan Tanpa Rokok terhadap penegakan disiplin masyarakat di kawasan umum. 


\section{DAFTAR PUSTAKA}

\section{Buku}

Abidin, Said Zainal. 2004. Kebijakan Publik. Jakarta: Penerbit Pancur Siwah.

Solichin, Abdul Wahab. 2004. Analisis Kebijakan: Dari Formulasi ke Implementasi Kebijakan Negara. Malang: Universitas Brawijaya Press.

Herrabudin. 2016. Studi Kebjakan Pemerintah Dari Filosofi Ke Implementasi. Bandung: Pustaka Setia.

Darmodiharjo, Darji. 1991. Peranan IKIP dalam Pengembangan dan Pembinaan sebagai Pusat Kebudayaan. Analisis Pendidikan. Bandung: Penerbit Alfabeta.

Tulus, Tu'u. 2004. Peranan Disiplin pada Perilaku dan Prestasi Belajar. Jakarta: Penerbit Grasindo.

Soekanto, Soerjono. 1983. Teori Sosiologi tentang Perubahan Sosial. Jakarta: Penerbit Ghalia Indonesia.

Soejono, Ag. 1980. Pendahuluan Ilmu Pendidikan Umum. Bandung: Penerbit CV. Ilmu.

Sugiyono. 2014. Metode Penelitian Administrasi, Penerbit Alfabeta, Bandung.

-. 2012. Metode Penelitian Kuantitatif, Kualitatif dan R\&D. Bandung: Penerbit Alfabeta.

\section{Jurnal}

Nerustia, Arinda Novpika; Rahmawati, Rita; dan Hernawan, Denny. 2015. Jurnal GOVERNANSI, p-ISSN 2442-3971 eISSN 2549-7138, Vol. 1, No. 1, April 2015, Halm. 49.

Lesmana, Wira; Rahmawati, Rita, dan Seran, G. Goris. 2017. "Implementasi Peraturan Daerah Kabupaten Bogor Nomor 11 Tahun 2012 Dalam Penataan Minimarket". Jurnal GOVERNANSI, pISSN 2442-3971 e-ISSN 2549-7138, Vol. 3, No. 1, April 2017, Halm. 5.

\section{Skripsi}

Setiawan, Nancy Purnamasari. 2017. Evaluasi Kebijakan Peraturan Daerah Kota
Bogor Nomor 12 Tahun 2009 tentang Kawasan Tanpa Rokok pada Sekolah Menengah Atas Negeri di Kota Bogor. Skripsi. Bogor: FISIP Universitas Djuanda.

\section{Peraturan}

Peraturan Daerah Kota Bogor Nomor 12 Tahun 2009 tentang Kawasan Tanpa Rokok. 